\title{
Nomenclature of
}

\section{Precambrian Rocks}

\section{in Colorado}

GE OLOG ICA L S URVEY BULLETIN 1422-D

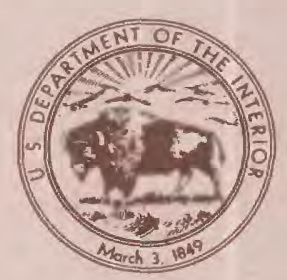





\section{Nomenclature of Precambrian Rocks in Colorado}

By OGDEN TWETO

C O N T R I B U T I O N S T O S T R A T I G R A P H Y

GE OLOGICAL SURVEY BULLETIN 1422-D

An appraisal of existing nomenclature and measures needed for improvement 


\section{UNITED STATES DEPARTMENT OF THE INTERIOR}

THOMAS S. KLEPPE, Secretary

\section{GEOLOGICAL SURVEY}

V. E. McKelvey, Director

Library of Congress Cataloging in Publication Data

Tweto, Ogden, 1912-

Nomenclature of Precambrian rocks in Colorado.

(Contributions to stratigraphy) (Geological Survey Bulletin 1422-D)

Bibliography: p.

Supt. of Docs. no.: I 19.3:1422-D

1. Geology, Stratigraphic-Pre-Cambrian. 2. Geology, Stratigraphic-NonmenclatureColorado.

I. Title. II. Series. III. Series: United States Geological Survey Bulletin 1422-D.

QE75.B9 no. 1422-D [QE653] 557'.3'08s [551.7'1'09788] 76-608373

For sale by the Superintendent of Documents, U.S. Government Printing Office Washington, D.C. 20402

Stock Number 024-001-02945-6 


\section{CONTENTS}

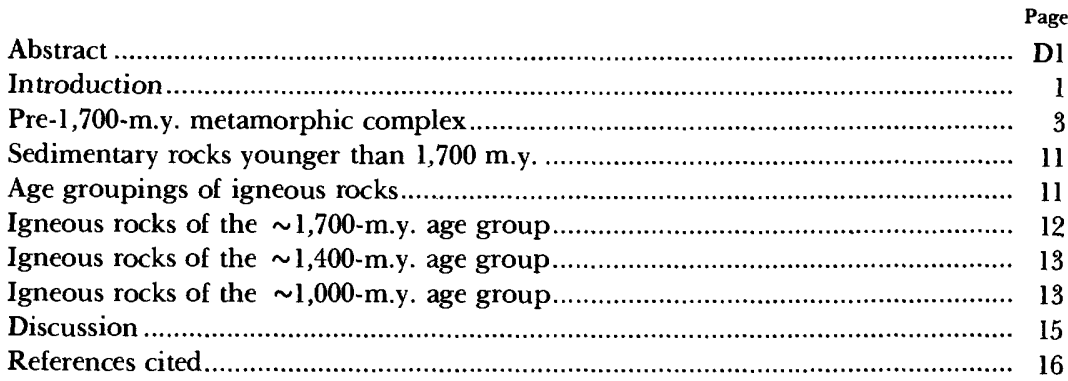

\section{ILLUSTRATION}

Page

Figure 1. Map of parts of Colorado and adjoining States showing distribution of Precambrian rocks

\section{TABLE}

TABLE 1. Classification of Precambrian rock units in Colorado. 



\title{
NOMENCLATURE OF PRECAMBRIAN ROCKS IN COLORADO
}

\author{
By Ogden Tweto
}

\begin{abstract}
The Precambrian rocks of Colorado consist of a metamorphic complex more than 1,700 million years in age, three groups of igneous rocks about $1,700,1,400$, and 1,000 nillion years in age, here designated informal age groups, and two areally restricted units of sedimentary rocks, one between 1,400 and 1,700 million years in age and one between 950 and 1,400 million years. A systematic nomenclature for many of the rocks does not exist, but the present state of knowledge will permit establishment of a comprehensive nomenclature. Numerous formal names that have been applied to elements of the Precambrian assemblage are appraised and classified in a table, and eight names are abandoned.
\end{abstract}

\section{INTRODUCTION}

As presently understood, the Precambrian rocks widely exposed in the mountains of Colorado (fig. 1) are a composite of six major age or genetic classes:

1. A metamorphic complex $>1,700$ m.y. (million years) in age.

2. A group of igneous rocks about $1,700 \mathrm{~m} . \mathrm{y}$. in age.

3. A unit (Uncompahgre Formation) of moderately metamorphosed sedimentary rocks $<1,700 \mathrm{~m}$.y. and $>1,400 \mathrm{~m}$.y. in age.

4. A group of igneous rocks about 1,400 m.y. in age.

5. A group of igneous rocks about 1,000 m.y. in age.

6. A unit (Uinta Mountain Group) of slightly metamorphosed sedimentary rocks provisionally dated as 950 to 1,400 m.y. in age.

No system of formal stratigraphic nomenclature exists for many of these rocks. Many stratigraphic names have been proposed, but most of them apply only to bits and pieces of the total assemblage. Before the advent of radiometric dating and widespread detailed mapping, many units were defined without knowledge of temporal relationships 
and with little consideration of their relation to rocks in other parts of the State or geologic province. Among those correlations that were made, many have subsequently proved faulty, and most of the few formal groups or "series" that were erected have proved to be based on faulty interpretations or assumptions. Thus, by a process of elimination, the nomenclature of Precambrian rocks in Colorado has been reduced to a rudimentary state. Fortunately, though no action has yet been taken, knowledge is now at hand to improve it.

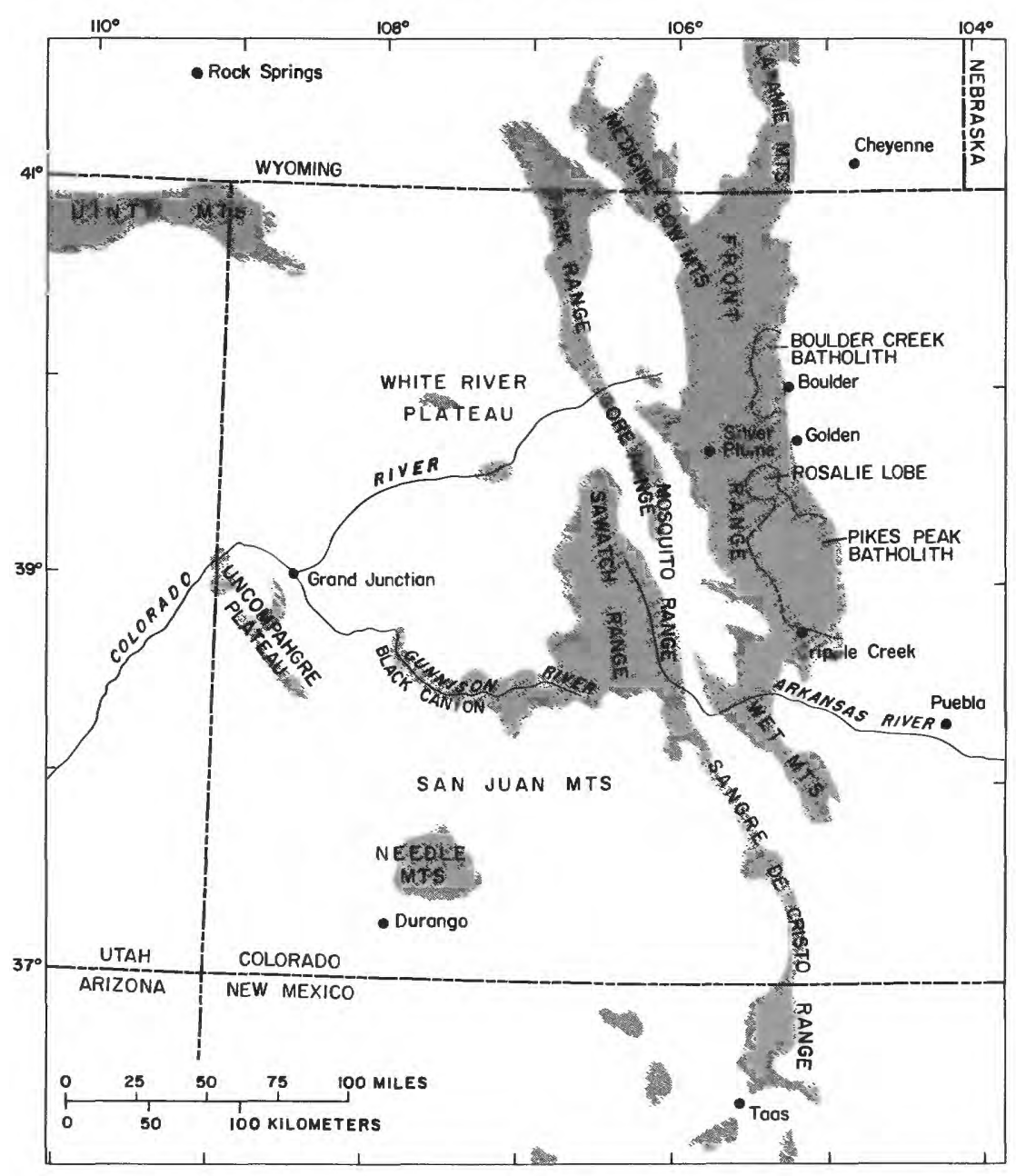

Figure 1.-Parts of Colorado and adjoining States showing distribution of Precambrian rocks (shaded areas) and localities mentioned in text and in table $\mathbf{1 .}$

A total of 93 formal names applied to Precambrian rocks is recorded in the U.S. Geological Survey's computer printout of stratigraphic names 
in Colorado. Though it is not the purpose here to denigrate the work of the past, the fact is that many of these names were inadequately defined or improperly introduced, and many that are technically valid are applicable only in minuscule type areas. A few names have been widely misapplied and have thereby lost whatever stratigraphic value they may have had originally. Still others have become obsolete through disuse or reclassification. Of all the names that have been proposed, only about 30 percent remain valid and in current use, and most of these are for igneous rocks.

As an outgrowth of the preparation of a new geologic map of Colorado, (Tweto, 1976), the formally named Precambrian stratigraphic units have been appraised and classified (table 1). For reasons indicated in the table and discussed under following headings, several names applied in the past by the U.S. Geological Survey are herein abandoned. Many other names, established by other parties, are obsolete or fail to meet the requirements of Article 13 of the Stratigraphic Code (American Commission on Stratigraphic Nomenclature, 1970). Use of such names without amendment or redefinition is inadvisable.

Though no attempt is made in this report to define new stratigraphic units appropriate to the Precambrian rocks, courses of action are considered in the section headed "Discussion."

\section{PRE-1,700-M.Y. METAMORPHIC COMPLEX}

A suite of complexly deformed metamorphic rocks of generally high rank forms a matrix for the abundant Precambrian igneous bodies in Colorado and a basement for the two younger Precambrian sedimentary sequences. This suite, herein referred to as the pre-1,700-m.y. metamorphic complex, consists of many varieties of metamorphic rocks, reflecting the permutations of varied parent materials, considerable range in degree of prograde metamorphism, wide range in degree of penetrative deformation, and wide range in degree of modification resulting either from igneous processes or retrograde metamorphism. The parent materials were evidently sedimentary, volcanic, and subvolcanic intrusive rocks. These ancestral rocks were in large discrete bodies in some places and closely interlayered or intertongued in others. They were a part of a huge province of rocks of similar age that are now irregularly exposed from southeastern Wyoming through Colorado into New Mexico and Arizona.

A minimum age for the rocks in the metamorphic complex is established by the fact that they were invaded by granites that are about 1,700 m.y. old. Geologic relations establish that metamorphism and folding both preceded and accompanied granitic intrusion. Radiometric age determinations indicate that regional metamorphism peaked in the period 1,700-1,775 m.y. ago in Colorado (Hedge and others, 1967; Hedge 


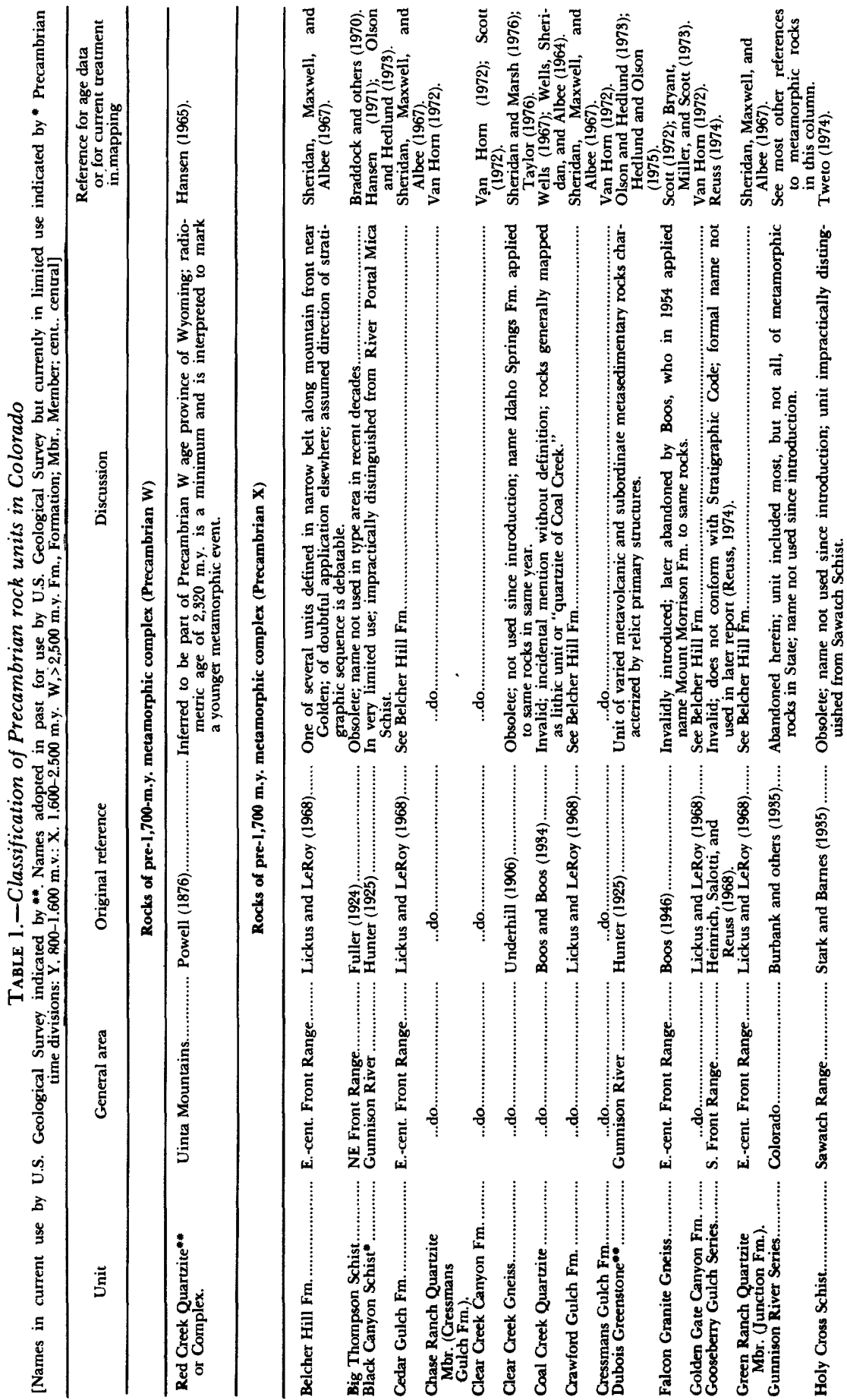




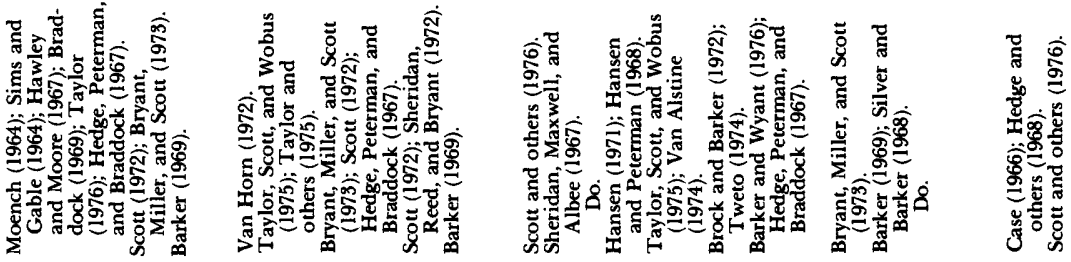

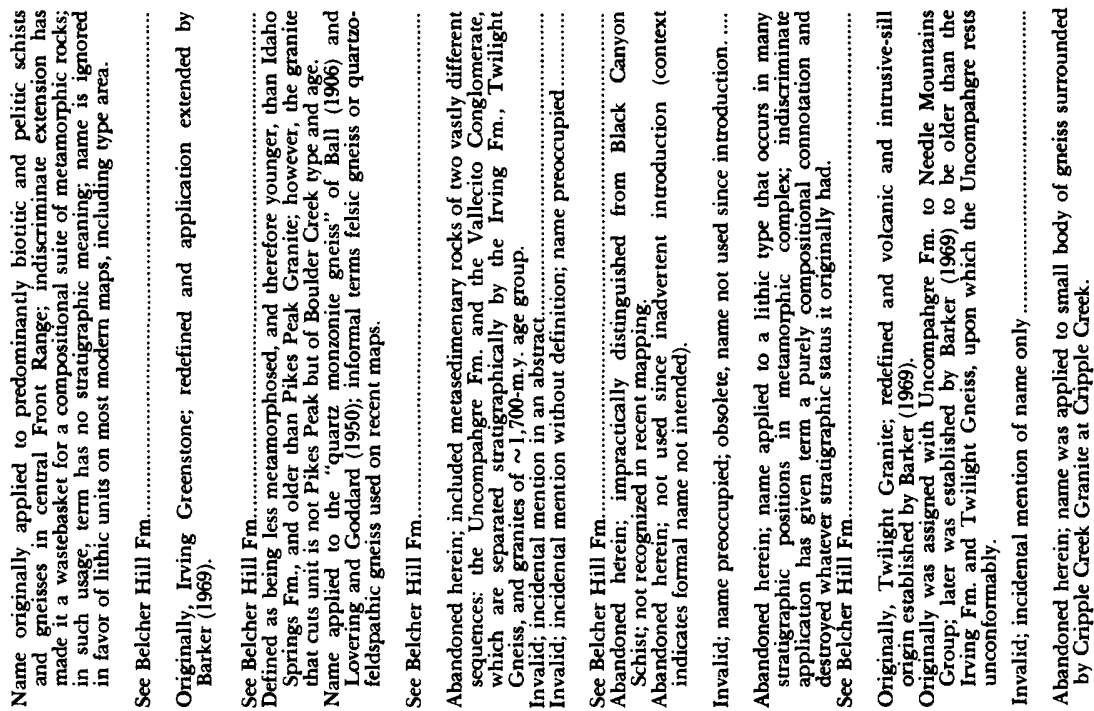

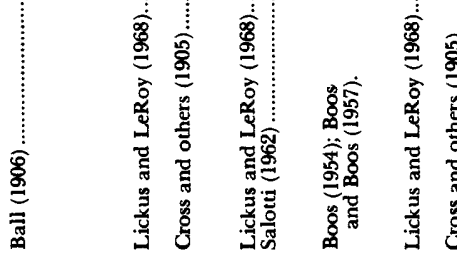

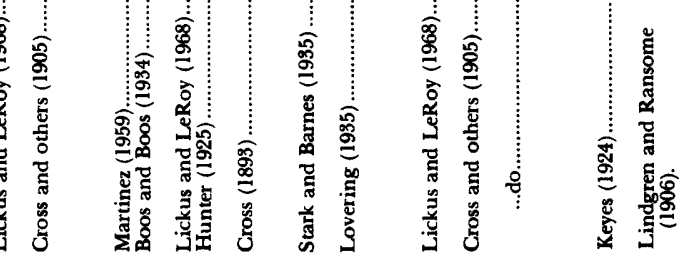

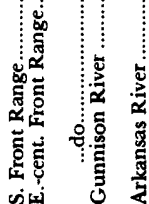

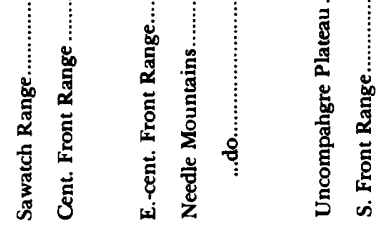

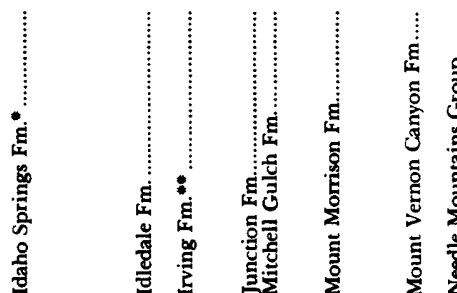

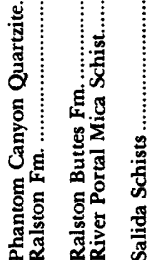

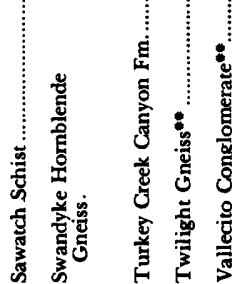

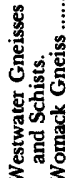




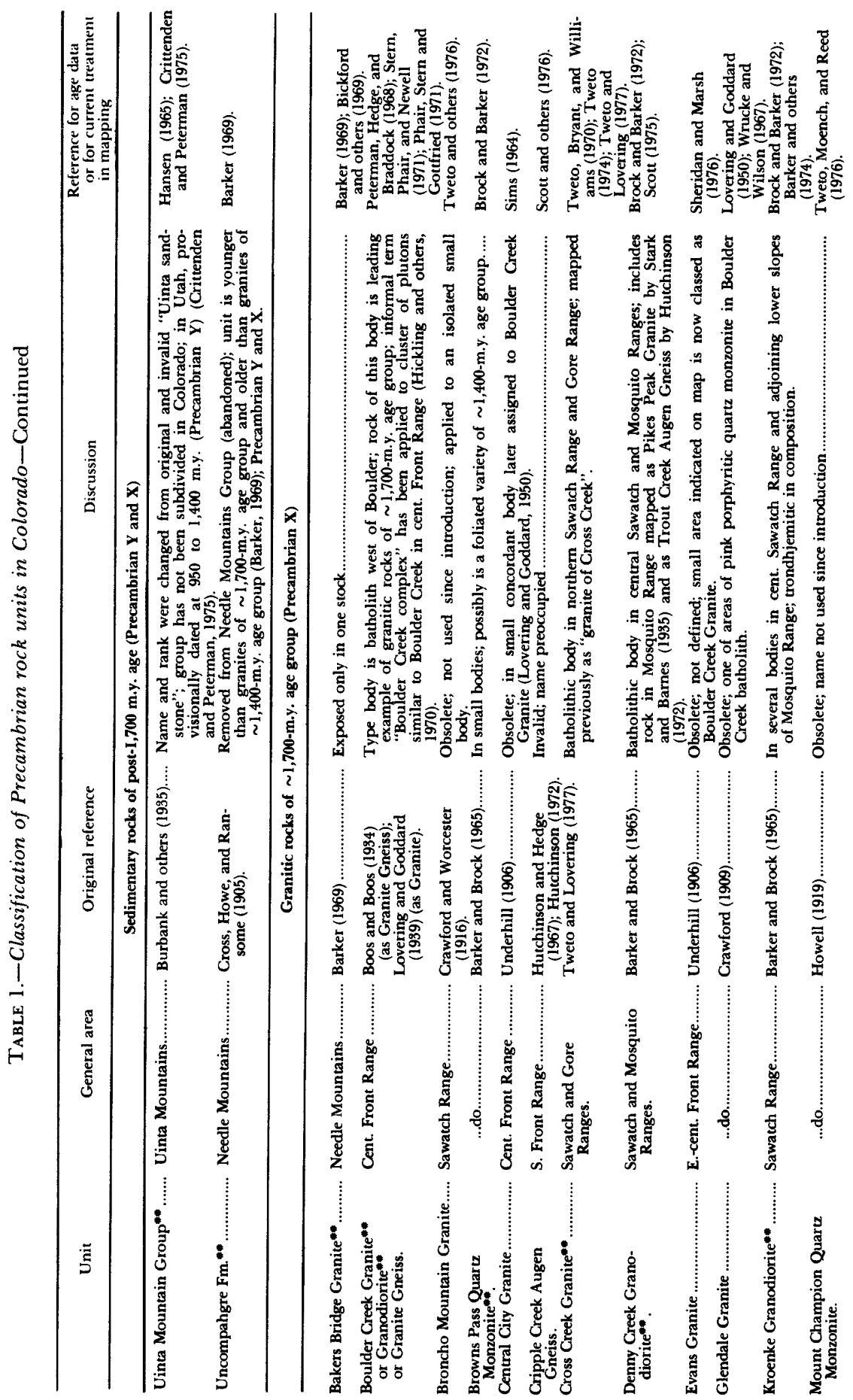




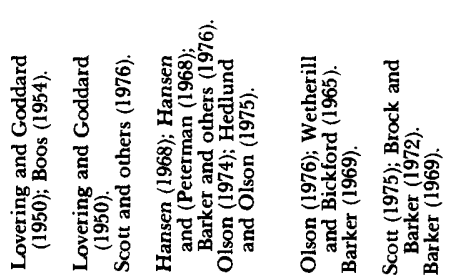

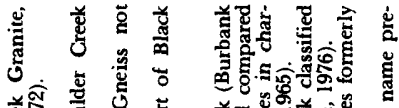

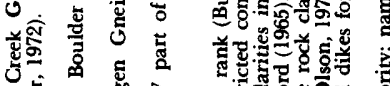

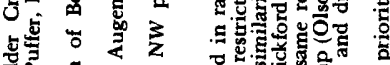

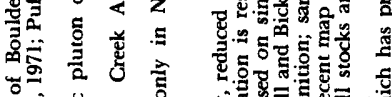

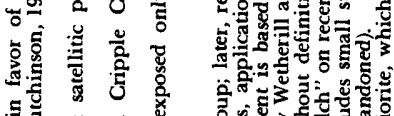

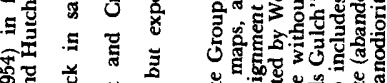

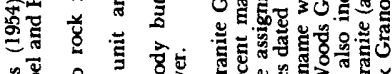

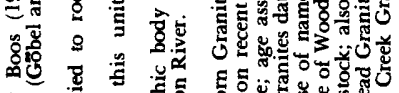

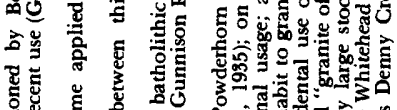

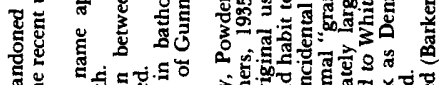

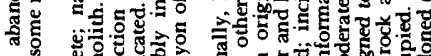

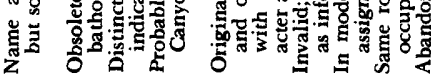

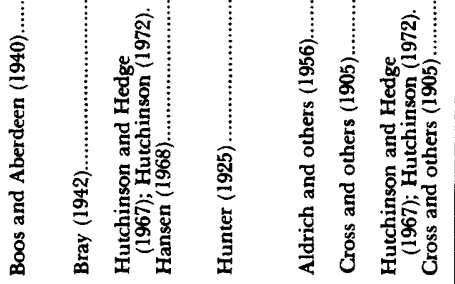

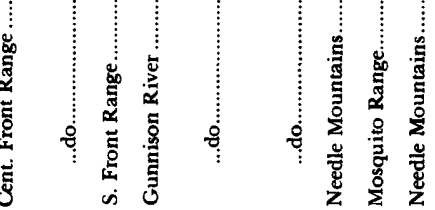

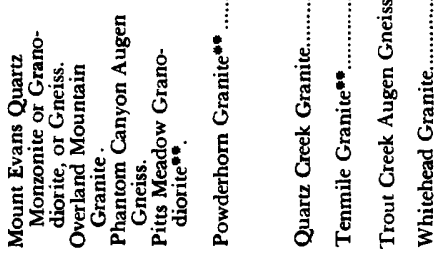

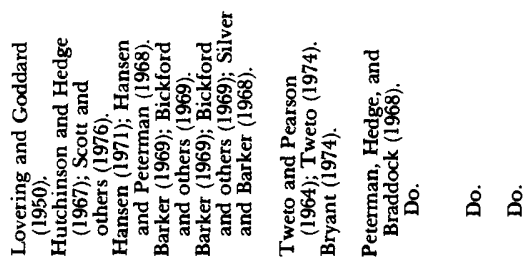

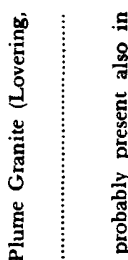

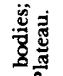

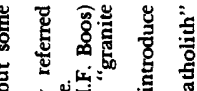
ב.

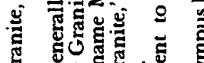
उु

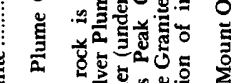

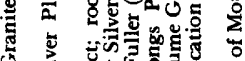

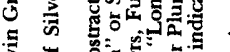

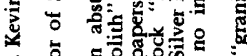
के 总 क 5 ज

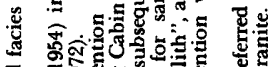
ฐ

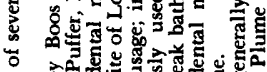

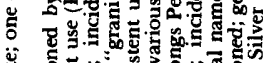

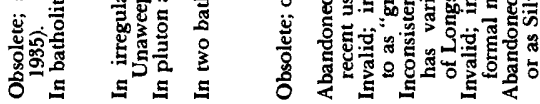

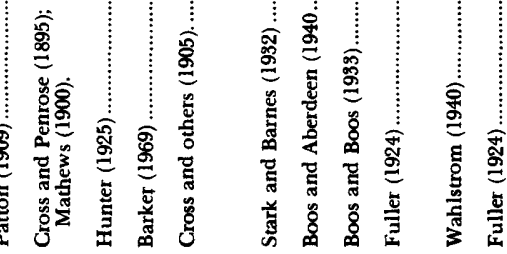

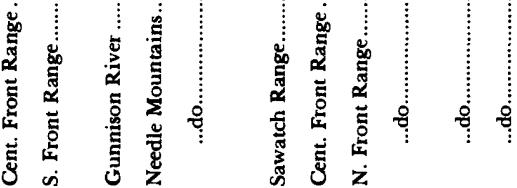

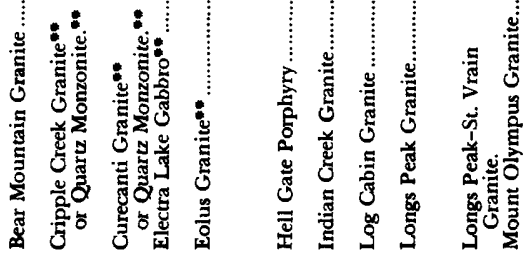




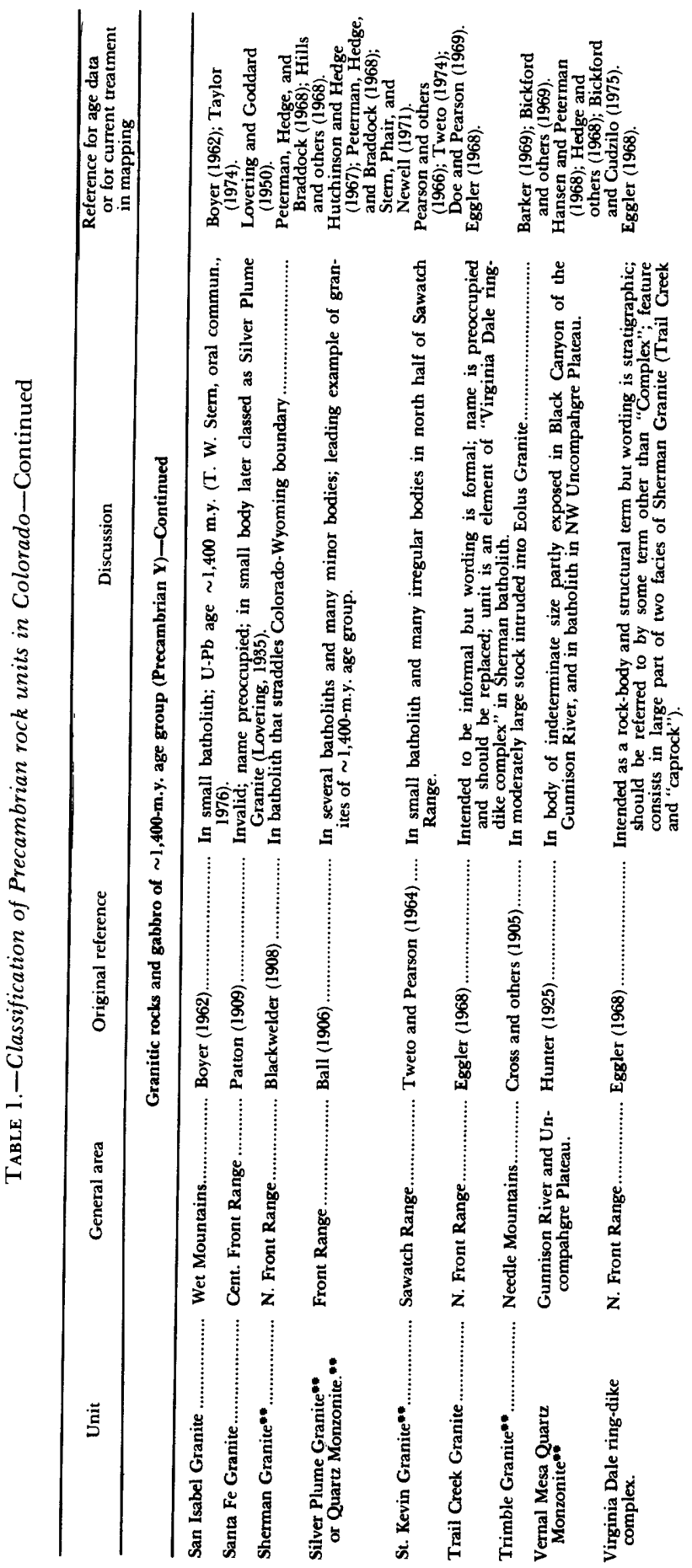


and others, 1968; Hansen and Peterman, 1968; Silver and Barker, 1968; Stern and others, 1971). Age of the rocks parent to the metamorphic rocks is not firmly established but apparently does not greatly exceed the age of metamorphism. Age in the range 1,750-1,820 m.y. has been determined from $\mathrm{U}-\mathrm{Pb}$ isotopic ratios in zircon in metaigneous rocks in the complex in southwestern Colorado (Silver and Barker, 1968), northern New Mexico (L. T. Silver, in Barker and Friedman, 1974), and central Arizona (Anderson and others, 1971). $\mathrm{Rb}$-Sr ratios indicate that metasedimentary rocks in the complex were not derived in any substantial part from an older crustal source such as the $>2,500$-m.y. Precambrian age province in Wyoming but were derived from rocks that were of mantle origin no more than 2,000 m.y. ago (Z. E. Peterman, oral commun., 1970). The one exception to these generalizations is the Red Creek Quartzite, which in Colorado occupies a very small area at the Utah border in the Uinta Mountains (fig. 1). This unit has a minimum age of 2,320 m.y. (Hansen, 1965 ), and it probably is part of the $>2,500-\mathrm{m}$.y. age province of Wyoming.

Many names have been applied to elements of the pre-1,700-m.y. metamorphic complex in Colorado (table 1), but only a few have survived the test of usage after introduction. In the Needle Mountains-isolated from other exposures of Precambrian rocks-the Vallecito Conglomerate, Irving Formation, and Twilight Gneiss are in stratigraphic sequence upward (Barker, 1969), and these long-established names remain in use. Elsewhere, the tendency in recent decades has been to forego formal names and to map on the basis of lithic units in the metamorphic complex. Two names that were widely applied in the past, Idaho Springs Formation and Swandyke Hornblende Gneiss, are falling or have fallen into disuse for two principal reasons: (1) The names have been applied so indiscriminately that they no longer convey any stratigraphic relationships but are only ambiguous synonyms for, respectively, the biotitic and the hornblendic gneisses, and (2) neither unit is of the proper rank either to serve any useful purpose in mapping or to serve as a collective term for diverse rocks that are untold miles in thickness. Additionally, neither unit embraces the great bodies of felsic gneiss now recognized to be metavolcanic and subvolcanic intrusive and to be interbedded with the other gneisses. The felsic gneiss was formerly thought to be plutonic quartz monzonite intruded into Idaho Springs and Swandyke.

For reasons detailed in table 1 , the following names applied in places to parts of the pre-1,700-m.y. metamorphic complex are herein abanoned:

Gunnison River Series Needle Mountains Group River Portal Mica Schist
Salida Schists Swandyke Hornblende Gneiss Womack Gneiss 


\section{SEDIMENTARY ROCKS YOUNGER THAN 1,700 M.Y.}

The two units of sedimentary rocks younger than 1,700 m.y.- the Uncompahgre Formation and the Uinta Mountain Group-are straightforward and require little comment. The Uncompahgre Formation (quartzite, slate, and phyllite) is removed from the Needle Mountain Group, which is herein abandoned. The Uncompahgre is bracketed in age between granites dated at 1,460 and 1,720 m.y. (Barker, 1969). It has no known counterpart in Colorado or in New Mexico outside the Needle Mountains. The nearest sedimentary and volcanic unit with which it might be partly contemporaneous is the Texas Gulch Formation in central Arizona (Anderson and others, 1971).

The Uinta Mountain Group is limited in Colorado to the Uinta Mountains and, largely in the subsurface, to a belt extending eastward to about long $107^{\circ}$ (Edwards, 1966). The group has not been subdivided in Colorado, where it consists of quartzite and sandstone as much as $24,000 \mathrm{ft}$ $(7.3 \mathrm{~km}$ ) thick (Hansen, 1965). On the basis of studies in Utah, the group is provisionally dated at 950 m.y. near the top and 1,400 m.y. at the base, and it is thus largely contemporaneous with the Belt Supergroup in Montana and Idaho (Crittenden and Peterman, 1975).

\section{AGE GROUPINGS OF IGNEOUS ROCKS}

Radiometric dates are now available for all the major types of Precambrian igneous rocks in Colorado and from all parts of the Precambrian terranes except the Sangre de Cristo Range. The dates fall statistically into three populations centered near 1,700, 1,400, and 1,000 m.y. The rocks of each of these age categories have generally distinctive characteristics, and though age determinations serve to corroborate their assignments, most of them are distinguishable on other grounds. In brief, the rocks that are about $1,700 \mathrm{~m}$.y. in age are generally syntectonic in habit, concordant, commonly foliated, and, among the granitoid facies, mainly granodioritic. Rocks that are about 1,400 m.y. in age are in general posttectonic in habit, discordant in some part, unfoliated or only locally foliated, and, among the granitoid facies, mainly quartz monzonitic to granitic in composition. Rocks that are about $1,000 \mathrm{~m}$.y. in age are anorogenic, discordant, unfoliated, and highly differentiated as indicated by the combination of siliceous granites, various syenites, and minor mafic facies.

Formal collective names for the rocks in each of the three age categories do not exist at this time. In the absence of such names, the informal term "age group" is used as a temporary means of identification. If Precambrian time were more finely divided and named than it is at present, 
an age-connoting name (comparable, for example, to "Jurassic rocks") could be substituted for "age group." The rocks of each age group were emplaced and crystallized at intervals through certain periods of time, but they do not define geologic time through those periods. Therefore, they do not meet the requirements of chronostratigraphic units.

\section{IGNEOUS ROCKS OF THE 1,700-M.Y. AGE GROUP}

Syntectonic igneous rocks ranging in age from about 1,650 to 1,730 m.y. are present in all the Precambrian terranes of Colorado except the Uinta Mountains. They range in composition from granite to gabbro. Granitoid rocks, principally granodiorite and quartz monzonite, are by far the most abundant. They occur in several batholiths, numerous smaller plutons, and countless small lenticular bodies. The rocks of some of the batholiths and smaller plutons bear formal names; those of many other bodies do not. The mafic rocks, principally gabbro, occur in widely scattered plutons, the largest of which has a diameter of $10 \mathrm{mi}(16 \mathrm{~km})$. None of the mafic rocks bear formal names.

The granitic rock generally recognized as most typical of the $\sim 1,700$ m.y. age group is the Boulder Creek Granite (or Granodiorite), which has been studied and mapped in considerable detail in the type batholith west of Boulder, Colo. (Lovering and Tweto, 1953; Wells, 1967; Wrucke and Wilson, 1967; Gable, 1972). The rock is also firmly dated at about 1,720 m.y. by both Rb-Sr and U-Pb (zircon) methods (Peterman and others, 1968; Stern and others, 1971; Phair and others, 1971). The name Boulder Creek has been extended beyond the type batholith and its satellites to plutons scattered through the $200-\mathrm{mi}(320-\mathrm{km})$ length of the Front Range (Lovering and Goddard, 1950, pl. 1), and, in informal usage at least, much farther. Considering the uncertainties inherent in longdistance correlation of igneous rocks, the recent practice of referring to rocks far removed from the type batholith as "of Boulder Creek type" or "of Boulder Creek age" is preferable.

The Cross Creek Granite of the Sawatch and Gore Ranges is dated at 1,715 m.y. (C. E. Hedge, written commun., 1973). The Denny Creek Granodiorite of the Sawatch and Mosquito Ranges probably is of a similar age as it is older than the Kroenke Granodiorite, which is dated at 1,700 m.y. (Barker and others, 1974). Granitic plutons on the southwest flank of the Sawatch Range have been dated at 1,650 \pm 35 m.y. (Wetherill and Bickford, 1965). This age may be too young; all the rocks are cataclasized and no completely fresh material has yet been found. Gneissic granodiorite in the Uncompahgre Plateau of extreme western Colorado is dated at 1,670 m.y. (Hedge and others, 1968), but this figure is also suspected to be too low (C. E. Hedge, written commun., 1976). However, dates somewhat below 1,700 m.y. are recorded to the south in New Mexico (Fullagar and Shiver, 1973) and to the southwest in Arizona (L. T. Silver, oral commun., 1974). 
In the past, granites of the $\sim 1,700-$ m.y. age group were widely miscorrelated with the much younger Pikes Peak Granite, as discussed in the section "Igneous rocks of $\sim 1,000$-m.y. age group."

\section{IGNEOUS ROCKS OF THE 1,400-M.Y. AGE GROUP}

Posttectonic igneous rocks ranging in age from about 1,350 to 1,480 m.y. are widely distributed in Colorado and are especially abundant in the Front Range. They are overwhelmingly of granitic or quartz monzonitic compositions, but alkalic and mafic compositions are also represented. The granitic rocks are in several batholiths and countless smaller bodies. Rocks of several of the batholiths bear formal names (table 1). Only one mafic rock, Electra Lake Gabbro, is formally named.

The rock generally recognized as most typical of the $\sim 1,400-\mathrm{m}$.y. age group is Silver Plume Granite, the type body of which is an irregular batholith northwest of Silver Plume in the central Front Range. The name Silver Plume has been widely extended from the type batholith, not only in the Front Range but in ranges to the west. However, the very considerable spread in ages of granites of this age group over the State as a whole dictates caution in extending the name beyond the central and northern Front Range.

The Silver Plume Granite is dated in different bodies at 1,390 to 1,450 m.y. (Peterman and others, 1968; Stern and others, 1971). The Sherman Granite, in a large batholith that extends into Colorado from Wyoming, is dated at 1,435 m.y. (C. E. Hedge, written commun., 1976) and is cut by Silver Plume Granite of the Log Cabin batholith (Peterman and others, 1968). The St. Kevin Granite in the Sawatch Range is of about the same age as the Silver Plume. The St. Kevin is dated at 1,470 165 m.y. by the Rb-Sr method and $1,410 \pm 40$ m.y. by the U-Pb method (Doe and Pearson, 1969). The Vernal Mesa Quartz Monzonite of western Colorado may be somewhat older, being dated at $1,480 \pm 40 \mathrm{~m}$.y. by the Rb-Sr method (Hansen and Peterman, 1968). The Eolus Granite, the principal granite of the $\sim 1,400-\mathrm{m} . y$. age group in the Needle Mountains, is closely dated at 1,466 \pm 27 m.y. by the Rb-Sr method (Bickford and others, 1969) and $1,460 \pm 20$ m.y. by the U-Pb method (Silver and Barker, 1968).

\section{IGNEOUS ROCKS OF THE 1,000-M.Y. AGE GROUP}

Rocks of the Pikes Peak batholith in the southern Front Range compose a $\sim 1,000-\mathrm{m} . \mathrm{y}$. age group. The batholith is composite, and several distinct intrusive units and rock types are distinguished within it. Four of the units or types have formal names (table 1), and several others are distinguished by rock names. Most of the batholith is referred to the Pikes Peak Granite, a term that in past usage has encompassed not only the coarse-grained pink to pale-orange biotite granite characteristic of the batholith but several other varieties of granite, syenite, and granodiorite (Barker and others, 1975; Hutchinson, 1960). The Mount Rosa, Windy 
Point, and Redskin Granites are intrusive into the Pikes Peak Granite.

Age of the Pikes Peak Granite and several of its associated rocks is $1,041 \pm 13$ m.y. as established from a whole-rock Rb-Sr isochron (Hedge, 1970). As shown by intrusive relations, certain rocks of the batholith are older than those represented in the isochron (Barker and others, 1975, fig. 3), and the Mount Rosa, Windy Point, and Redskin Granites are all younger. However, the entire assemblage is interpreted to be cogenetic (Barker and others, 1975) and may have been emplaced within a time span of no more than 20 m.y. (Hedge, 1970).

In the past, the name Pikes Peak was widely misapplied to granites of Boulder Creek type and age, with the result that the Pikes Peak Granite was once classed as the oldest granite in the Front Range (Lovering, 1929). At its south end, the Pikes Peak batholith is in contact with a granodiorite of the Boulder Creek type. For many years, and as late as 1950 (Lovering and Goddard, 1950, pl. 1), the granodiorite was assumed to be a part of the Pikes Peak batholith and, therefore, to be a variety of Pikes Peak Granite. Similarly, north of a satellitic pluton called the Rosalie lobe of the Pikes Peak batholith, granite of Boulder Creek type was assigned by Lovering (1929) to the Pikes Peak. These misassignments led to further misassignments in ranges to the west, where, in several localities, rocks of the $\sim 1,700$-m.y. age group were dubbed Pikes Peak Granite (Stark and Barnes, 1935; Stark and others, 1949; Behre, 1953; Dings and Robinson, 1957).

Confusion over the age of the Pikes Peak Granite relative to granites of the $\sim 1,400-\mathrm{m}$.y. age group began at an early date. Because the Cripple Creek Granite of the $\sim 1,400-m$.y. age group is finer grained than the Pikes Peak, it was judged to be the younger by Mathews (1900). On the grounds of being less sheared than granodiorite that was erroneously assumed to be Pikes Peak, the Cripple Creek was also judged to be the younger by L. C. Graton (in Lindgren and Ransome, 1906). Further, Finlay (1916) erroneously assigned fine-grained dike rocks that cut Pikes Peak Granite to the Cripple Creek. In the central and northern Front Range, similar confusion prevailed with respect to the Silver Plume Granite. Because of the misassignment of granitic rocks of the Boulder Creek type to Pikes Peak Granite, the Silver Plume Granite was long interpreted to be younger than the Pikes Peak Granite (Lovering, 1929; Lovering and Goddard, 1939, 1950; Boos and Aberdeen, 1940; Lovering and Tweto, 1953). This interpretation was supported by yet another miscorrelation: On the basis of a general resemblance, the Sherman Granite was correlated with the Pikes Peak, and the Sherman is observed to be cut by Silver Plume Granite as noted under the preceding heading.

For reasons indicated in table 1, the names Spring Creek Granite and Front Range Granite Group are herein abandoned. 


\section{DISCUSSION}

A need clearly exists for a systematic nomenclature for Precambrian rocks in Colorado. The state of knowledge is now well enough advanced to begin establishment of such a nomenclature. In particular, the three age groups of igneous rocks warrant formal designation. However, a problem exists in adapting them to the Stratigraphic Code as now worded (American Commission on Stratigraphic Nomenclature, 1970). The age groups would logically become formal rock-stratigraphic groups or, conceivably, supergroups. The problem lies in the fact that "a group consists wholly of divisions defined as formations" and a supergroup is "a formal assemblage of related groups or of formations and groups" (Stratigraphic Code, Article 9). The igneous age groups, on the other hand, consist not only of named units (formations) but of numerous unnamed rocks.

The mechanism of assigning group rank to a name used in one area and formation rank to the same name in another area (permitted by the Code, Article 9) would not be a satisfactory solution to the problem because the named and unnamed igneous rocks are intersprinkled throughout the Precambrian terranes. An area as small as a 71/2-minute quadrangle might then require two ranks for the same name, and this obviously is not practical.

One of three courses of action would be necessary to fit the age groups into the existing Code:

1. Apply formal names to the unnamed rocks. Considering the great number of names that would be required, this course is hardly practical and is certainly undesirable.

2. Classify all the unnamed rocks of an age group into one of the named units or, possibly, into one of a few newly defined units. This course, akin to hammering a square peg into a round hole, is undesirable because it would equate rocks that might be of different character, mode of occurrence, position in intrusive sequence, or many millions of years apart in age. Much of the confusion in nomenclature and rock sequence that has existed in the past resulted from unwise extension of names.

3. Establish the age groups as formations and reduce the presently named units to rank of members. (The Stratigraphic Code, Article 9, allows a mixture of named and unnamed members in a formation.) This course would not befit the magnitude and diversity of the age groups. Units such as Boulder Creek, Silver Plume, and Pikes Peak are each divisible into units that are logical members or even formations. 
A committee within the American Commission on Stratigraphic Nomenclature is currently (1976) examining the question of whether the Stratigraphic Code should be amended to provide more realistically for the stratigraphic problems peculiar to plutonic and metamorphic rocks and characteristic of many Precambrian terranes. Pending the outcome, establishment of a formal nomenclature for the igneous age groups should be deferred. In the interim, it is possible to classify rocks and communicate unambiguously by referring rocks to the informal age groups used here.

The problems with the pre-1,700-m.y. metamorphic complex differ from those with the igneous rocks. Radiometric dating has not been applicable thus far to subdivision of the complex because of the effects of metamorphism and because the analytical uncertainties in age determinations are of the same order as the time span in which the parent rocks of the complex apparently were deposited ( 50-75 m.y.). Stratigraphic relations in the metamorphic complex are obscured by multiple folding, partial melting and flowage to the point of structural disorganization in some places, differences in metamorphic grade in different areas, large displacements on Precambrian faults of both premetamorphic and postmetamorphic age, and losses of continuity owing to batholithic intrusion. A large amount of the detailed mapping necessary to overcome these obstacles has been accomplished in the last two decades. Though additional mapping is needed, enough has been done to allow the beginning of regional studies to establish a stratigraphic framework within the metamorphic complex. Until such a framework is established in at least major areas of the Precambrian terranes, there is little point in defining additional formal stratigraphic units in the complex. Meanwhile, informal lithic units can continue to serve the needs in mapping and other studies.

Whatever nomenclatures may be established, they are not limited to Colorado. Various units of the Precambrian rocks of Colorado extend across State lines into New Mexico, Wyoming, and Utah.

\section{REFERENCES CITED}

Aldrich, L. T., Davis, G. L., Tilton, G. R., and Wetherill, G. W., 1956, Radioactive ages of minerals from the Brown Derby mine and the Quartz Creek Granite near Gunnison, Colorado: Jour. Geophys. Research, v. 61, no. 2, p. 215-232.

American Commission on Stratigraphic Nomenclature, 1970, Code of stratigraphic nomenclature: Tulsa, Am. Assoc. Petroleum Geologists, 22 p.

Anderson, C. A., Blacet, P. M., Silver, L. T., and Stern, T. W., 1971, Revision of Precambrian stratigraphy in the Prescott-Jerome area, Yavapai County, Arizona: U.S. Geol. Survey Bull. 1324-C, 16 p.

Ball, S. H., 1906, Precambrian rocks of the Georgetown quadrangle, Colorado: Am. Jour. Sci., 4th ser., v. 21, p. 371-389.

Barker, Fred, 1969, Precambrian geology of the Needle Mountains, southwestern Colorado: U.S. Geol. Survey Prof. Paper 644-A, 35 p. 
Barker, Fred, Arth, J. G., Peterman, Z. E., and Friedman, Irving, 1976, The 1.7- to 1.8-b.y.-old trondhjemites of southwestern Colorado and northern New MexicoGeochemistry and depth of genesis: Geol. Soc. America Bull., v. 87, no. 2, p. 189-198.

Barker, Fred, and Brock, M. R., 1965, Denny Creek Granodiorite Gneiss, Browns Pass Quartz Monzonite, and Kroenke Granodiorite, Mount Harvard quadrangle, Colorado, in Changes in stratigraphic nomenclature by the U.S. Geological Survey 1964: U.S. Geol. Survey Bull. 1224-A, p. A23-A26.

Barker, Fred, and Friedman, Irving, 1974, Precambrian metavolcanic rocks of the Tusas Mountains, New Mexico-Major elements and oxygen isotopes: New Mexico Geol. Soc. Guidebook, 25th Field Conf., Ghost Ranch (Central-Northern New Mexico), p. 115-117.

Barker, Fred, Peterman, Z. E., Henderson, W. T., and Hildreth, R. E., 1974, Rubidiumstrontium dating of the trondhjemite of Rio Brazos, New Mexico, and of the Kroenke Granodiorite, Colorado: U.S. Geol. Survey Jour. Research, v. 2, no. 6, p. 705-709.

Barker, Fred, Wones, D. R., Sharp, W. N., and Desborough, G. A., 1975, The Pikes Peak batholith, Colorado Front Range, and a model for the origin of the gabbroanorthosite-syenite-potassic granite suite: Precambrian Research, v. 2, p. 97-160.

Barker, Fred, and Wyant, D. C., 1976, Geologic map of the Jefferson quadrangle, Colorado: U.S. Geol. Survey Geol. Quad. Map GQ-1345 (in press).

Behre, C. H., Jr., 1953, Geology and ore deposits of the west slope of the Mosquito Range [Colorado]: U.S. Geol. Survey Prof. Paper 235, 176 p.

Bickford, M. E., and Cudzilo, T. F., 1975, U-Pb age of zircon from Vernal Mesa-type quartz monzonite, Unaweep Canyon, west-central Colorado: Geol. Soc. America Bull., v. 86, no. 10, p. 1432-1434.

Bickford, M. E., Wetherill, G. W., Barker, Fred, and Lee-Hu, Chin-Nan, 1969, Precambrian Rb-Sr chronology in the Needle Mountains, southwestern Colorado: Jour. Geophys. Research, v. 74, no. 6, p. 1660-1676.

Blackwelder, Eliot, 1908, Precambrian rocks in southeastern Wyoming: Science, new ser., v. 27 , no. 698 , p. 787-788.

Boos, M. F., 1946, Genesis of pegmatites in the Denver Mountain Parks area, Colorado [abs.]: Geol. Soc. America Bull., v. 57, no. 12, pt. 2, p. 1179.

Boos, M. F., 1954, Genesis of Precambrian granitic pegmatites in the Denver Mountain Parks area, Colorado: Geol. Soc. America Bull., v. 65, no. 2, p. 115-142.

Boos, M. F., and Aberdeen, Esther, 1940, Granites of the Front Range, Colorado-The Indian Creek plutons: Geol. Soc. America Bull., v. 51, no. 5, p. 695-730.

Boos, M. F., and Boos, C. M., 1933, Granites of the Front Range-The Log Cabin batholith [abs.]: Geol. Soc. America Proc., 1933, p. 69 [1934].

1934, Granites of the Front Range-The Longs Peak-St. Vrain batholith: Geol. Soc. America Bull., v. 45, no. 2, p. 303-322.

Boos, C. M., and Boos, M. F., 1957, Tectonics of eastern flank and foothills of Front Range, Colorado: Am. Assoc. Petroleum Geologists Bull., v. 41, no. 12, p. 2603-2676.

Boyer, R. E., 1962, Petrology and structure of the southern Wet Mountains, Colorado: Geol. Soc. America Bull., v. 73, no. 9, p. 1047-1070.

Braddock, W. A., 1969, Geology of the Empire quadrangle, Grand, Gilpin, and Clear Creek Counties, Colorado: U.S. Geol. Survey Prof. Paper 616, 56 p.

Braddock, W. A., Prinya, Nutalaya, Gawarecki, S. J., and Curtin, G. C., 1970, Geologic map of the Drake quadrangle, Larimer County, Colorado: U.S. Geol. Survey Geol. Quad. Map GQ-829.

Bray, J. M., 1942, Spectroscopic distribution of minor elements in igneous rocks from Jameswown, Colorado: Geel. Sec. America Bull., v. 53, no. 5, p. 765-814. 
Brock, M. R., and Barker, Fred, 1972, Geologic map of the Mount Harvard quadrangle, Chaffee and Gunnison Counties, Colorado: U.S. Geol. Survey Geol. Quad. Map GQ-952.

Bryant, Bruce, 1974, Reconnaissance geologic map of the Conifer quadrangle, Jefferson County, Colorado: U.S. Geol. Survey Misc. Field Studies Map MF-597.

Bryant, Bruce, Miller, R. D., and Scott, G. R., 1973, Geologic map of the Indian Hills quadrangle, Jefferson County, Colorado: U.S. Geol. Survey Geol. Quad. Map GQ-1073 [1974].

Burbank, W. S., Lovering, T. S., Goddard, E. N., and Eckel, E. B., 1935, Geologic map of Colorado: U.S. Geol. Survey.

Case, J. E., 1966, Geophysical anomalies over Precambrian rocks, northwestern Uncompahgre Plateau, Utah and Colorado: Am. Assoc. Petroleum Geologists Bull., v. 50 , no. 7 , p. $1423-1443$.

Crawford, R. D., 1909, Geology and petrography of the Sugarloaf district, Boulder County, Colorado: Colorado Univ. Studies, v. 6, p. 97-131.

Crawford, R. D., and Worcester, P. G., 1916, Geology and ore depsoits of the Gold Brick district, Colorado: Colorado Geol. Survey Bull. 10, 116 p.

Crittenden, M. D., Jr., and Peterman, Z. E., 1975, Provisional Rb/Sr age of the Precambrian Uinta Mountain Group, northeastern Utah: Utah Geology, v. 2, no. 1, p. 75-77.

Cross, Whitman, 1893, On a series of peculiar schists near Salida, Colorado: Colorado Sci. Soc. Proc., v. 4, p. 286-293.

1894, Description of the Pikes Peak sheet [Colorado]: U.S. Geol. Survey Geol. Atlas, Folio 7, 8 p.

Cross, Whitman, Howe, Ernest, Irving, J. D., and Emmons, W. H., 1905, Description of the Needle Mountains quadrangle [Colorado]: U.S. Geol. Survey Geol. Atlas, Folio $131,14 \mathrm{p}$.

Cross, Whitman, Howe, Ernest, and Ransome, F. L., 1905, Description of the Silverton quadrangle [Colorado]: U.S. Geol. Survey Geol. Atlas, Folio 120, 34 p.

Cross, Whitman, and Penrose, R. A. F., Jr., 1895, Geology and mining industries of the Cripple Creek district, Colorado: U.S. Geol. Survey 16th Ann. Rept., pt. 2, p. 1-209.

Dings, M. G., and Robinson, C. S., 1957, Geology and ore deposits of the Garfield quadrangle, Colorado: U.S. Geol. Survey Prof. Paper 289, 110 p.

Doe, B. R., and Pearson, R. C., 1969, U-Th-Pb chronology of zircons from the St. Kevin Granite, northern Sawatch Range, Colorado: Geol. Soc. America Bull., v. 80, no. 12 , p. 2495-2502.

Edwards, Jonathan, Jr., 1966, The petrology and structure of the buried Precambrian basement of Colorado: Colorado School Mines Quart., v. 6l, no. 4, 436 p.

Eggler, D. H., 1968, Virginia Dale Precambrian ring-dike complex, Colorado-Wyoming: Geol. Soc. America Bull., v. 79, no. 11, p. 1545-1564.

Finlay, G. I., 1916, Description of the Colorado Springs quadrangle [Colorado]: U.S. Geol. Survey Geol. Atlas, Folio 203, 16 p.

Fullagar, P. D., and Shiver, W. S., 1973, Geochronology and petrochemistry of the Embudo Granite, New Mexico: Geol. Soc. America Bull., v. 84, no. 8, p. 2705-2712.

Fuller, M. B., 1924, General features of Precambrian structure along the Big Thompson River in Colorado: Jour. Geology, v. 32, no. 1, p. 49-63.

Gable, D. J., 1972, Geologic map of the Tungsten quadrangle, Boulder, Gilpin, and Jefferson Counties, Colorado: U.S. Geol. Survey Geol. Quad. Map GQ-978.

George, R. D., 1913, Geologic map of Colorado: Colorado Geol. Survey.

Göbel, Volker, and Hutchinson, R. M., 1971, Metablastesis and anatexis in Precambrian rocks, Mt. Evans area, central Front Range, Colorado: Geol. Soc. America Abstracts with Programs, v. 3, no. 6, p. 382. 
Gross, E. B., and Heinrich, E. W., 1965, Petrology and mineralogy of the Mount Rosa area, EI Paso and Teller Counties, Colorado, Part I-The granites: Am. Mineralogist, v. 50, no. 9, p. 1273-I295.

Hansen, W. R., 1965, Geology of the Flaming Gorge area, Utah-Colorado-Wyoming: U.S. Geol. Survey Prof. Paper 490, 196 p.

1968, Geologic map of the Black Ridge quadrangle, Delta and Montrose Counties, Colorado: U.S. Geol. Survey Geol. Quad. Map GQ-747.

1971, Geologic map of the Black Canyon of the Gunnison River and vicinity, western Colorado: U.S. Geol. Survey Misc. Geol. Inv. Map I-584.

Hansen, W. R., and Peterman, Z. E., 1968, Basement-rock geochronology of the Black Canyon of the Gunnison, Colorado, in Geological Survey Research 1968: U.S. Geol: Survey Prof. Paper 600-C, p. C80-C90.

Hawley, C. C., 1969, Geology and beryllium deposits of the Lake George (or Badger Flats) beryllium area, Park and Jefferson Counties, Colorado: U.S. Geol. Survey Prof. Paper 608-A, 44 p.

Hawley, C. C., Huffman, Claude, Jr., Hamilton, J. C., and Rader, L. F., Jr., 1966, Geologic and geochemical features of the Redskin Granite and associated rocks, Lake George beryllium area, Colorado, in Geological Survey Research 1966: U.S. Geol. Survey Prof. Paper 550-C, p. Cl38-C147.

Hawley, C. C., and Moore, F. B., 1967, Geology and ore deposits of the Lawson-DumontFall River district, Clear Creek County, Colorado: U.S. Geol. Survey Bull. 1231, $92 \mathrm{p}$.

Hedge, C. E., 1970, Whole-rock $\mathrm{Rb} / \mathrm{Sr}$ age of the Pikes Peak batholith, Colorado, in Geological Survey Research 1970: U.S. Geol. Survey Prof. Paper 700-B, p. B86-B89.

Hedge, C. E., Peterman, Z. E., and Braddock, W. A., 1967, Age of the major Precambrian regional metamorphism in the northern Front Range, Colorado: Geol. Soc. America Bull., v. 78, no. 4, p. 551-558.

Hedge, C. E., Peterman, Z. E., Case, J. E., and Obradovich, J. D., 1968, Precambrian geochronology of the northwestern Uncompahgre Plateau, Utah and Colorado, in Geological Survey Research 1968: U.S. Geol. Survey Prof. Paper 600-C, p. C9I-C96.

Hedlund, D. C., and OIson, J. C., 1975, Geologic map of the Powderhorn quadrangle, Gunnison and Saguache Counties, Colorado: U.S. Geol. Survey Geol. Quad. Map GQ-1178.

Heinrich, E. W., Salotti, C. A., and Reuss, R. L., 1968, New Precambrian metamorphic series in south-central Colorado [abs.]: Geol. Soc. America Spec. Paper 115, p. $389-390$.

Hickling, N. L., Phair, George, Moore, Roosevelt, and Rose, H. J., Jr., I970, Boulder Creek batholith, Colorado, Part I-Allanite and its bearing upon age patterns: Geol. Soc. America Bull., v. 81, no. 7, p. 1973-1994.

Hills, F. A., Gast, P. W., Houston, R. S., and Swainbank, I. G., 1968, Precambrian geochronology of the Medicine Bow Mountains, southeastern Wyoming: Geol. Soc. America Bull., v. 79, no. 12, p. 1757-1784.

Hinds, N. E. A., 1936, Uncompahgran and Beltian deposits in western North America, in Contributions to Precambrian geology of western North America: Carnegie Inst. Washington Pub. 463, p. 53-136.

Howell, J. V., 1919, Twin Lakes district of Colorado: Colorado Geol.'Survey Bull. 17, $106 \mathrm{p}$.

Hunter, J. F., 1925, Precambrian rocks of Gunnison River, Colorado: U.S. Geol. Survey Bull. 777, 94 p.

Hutchinson, R. M., 1960, Structure and petrology of north end of Pikes Peak batholith, Colorado, in Weimer, R. J., and Haun, J. D., eds., Guide to the geology of Colorado: Geol. Soc. America, Rocky Mtn. Assoc. Geologists, and Colorado Sci. Soc., p. 170-180. 
1972, Pikes Peak batholith and Precambrian basement rocks of the central Colorado Front Range-Their 700-million-year history, in Precambrian geology, Section l: Internat. Geol. Cong., 24th, Montreal, 1972, Proc., no. 24, p. 201-212.

Hutchinson, R. M., and Hedge, C. E., 1967, Precambrian basement rocks of the central Colorado Front Range and its 700 million year history: Geol. Soc. America Rocky Mtn. Sect., Guidebook for Field Trip No. 1, Golden Mtng., 1967, 51 p.

Keyes, C. R., 1924, Grand staircase of Utah: Pan-Am. Geologist, v. 41, no. 1, p. 33-68.

Lickus, R. J., and LeRoy, L. W., 1968, Precambrian structure and stratigraphy along the mountain front west of Golden, Jefferson County, Colorado-a reconnaissance study, in Geophysical and geological studies of the relationships between the Denver earthquake and the Rocky Mountain Arsenal well, Part A: Colorado School Mines Quart., v. 63, no. 1, p. 129-165.

Lindgren, Waldemar, and Ransome, F. L., 1906, Geology and gold deposits of the Cripple Creek district, Colorado: U.S. Geol. Survey Prof. Paper 54, 516 p.

Lovering, T. S., 1929, Geologic history of the Front Range, Colorado: Colorado Sci. Soc. Proc., v. 12, no. 4, p. 59-111.

1935, Geology and ore deposits of the Montezuma quadrangle, Colorado: U.S. Geol. Survey Prof. Paper 178, 119 p.

Lovering, T. S., and Goddard, E. N., 1939, Geologic map of the Front Range mineral belt, Colorado [Explanatory text]: Colorado Sci. Soc. Proc., v. 14, no. 1, p. 3-48.

1950, Geology and ore deposits of the Front Range, Colorado: U.S. Geol. Survey Prof. Paper 223, 319 p. [1951].

Lovering, T. S., and Tweto, Ogden, 1953, Geology and ore deposits of the Boulder County tungsten district, Colorado: U.S. Geol. Survey Prof. Paper 245, 199 p.

Martinez, J. D., 1959, The application of the photometer method in determining the crystallographic fabric of quartz in metamorphic quartzites: Dissert. Abs., v. 20, no. 3, p. 995-996.

Mathews, E. B., 1900, The granitic rocks of the Pikes Peak quadrangle: Jour. Geology, v. 8, no. 3, p. 214-240.

Moench, R. H., 1964, Geology of Precambrian rocks, Idaho Springs district, Colorado: U.S. Geol. Survey Bull. 1182-A, 70 p.

OIson, J. C., 1974, Geologic map of the Rudolph Hill quadrangle, Gunnison, Hinsdale, and Saguache Counties, Colorado: U.S. Geol. Survey Geol. Quad. Map GQ-1177 [1975].

Olson, J. C., 1976, Geologic map of the Houston Gulch quadrangle, Gunnison and Saguache Counties, Colorado: U.S. Geol. Survey Geol. Quad. Map GQ-1287.

Olson, J. C., and Hedlund, D. C., 1973, Geologic map of the Gateview quadrangle, Gunnison County, Colorado: U.S. Geol. Survey Geol. Quad. Map GQ-1071 [1974].

Patton, H. B., 1909, The Montezuma mining district of Summit County, Colorado: Colorado Geol. Survey First Rept., 1908, p. 105-144.

Pearson, R. C., Hedge, C. E., Thomas, H. H., and Stern, T. W., 1966, Geochronology of the St. Kevin Granite and neighboring Precambrian rocks, northern Sawatch Range, Colorado: Geol. Soc. America Bull., v. 77, no. 10, p. 1109-1120.

Peterman, Z. E., Hedge, C. E., and Braddock, W. A., 1968, Age of Precambrian events in the northeastern Front Range, Colorado: Jour. Geophys. Research, v. 73, no. 6, p. 2277-2296.

Phair, George, Stern, T. W., and Gottfried, David, 1971, Boulder Creek batholith, Colorado, Part III-Fingerprinting discordant zircon ages in a complex intrusion: Geol. Soc. America Bull., v. 82, no. 6, p. 1635-1656.

Powell, J. W., 1876, Report on the geology of the eastern portion of the Uinta Mountains and a region of country adjacent thereto: U.S. Geol. Geog. Survey Terr. (Powell), v. 7,218 p. 
Puffer, J. H., 1972, Iron-bearing minerals as indicators of intensive variables pertaining to granitic rocks from the Pegmatite Points area, Colorado: Am. Jour. Sci., v. 272, no. 3, p. 273-289.

Reuss, R. L., 1974, Precambrian quartzite-schist sequence in Wilson Park, Fremont County, Colorado: Mountain Geologist, v. I1, no. 2, p. 45-58A.

Salotti, C. A., 1962, Anthophyllite within the albite-epidote hornfels facies, Fremont County, Colorado: Am. Mineralogist, v. 47, no. 9-10, p. 1055-1066.

Scott, G. R., 1972, Geologic map of the Morrison quadrangle, Jefferson County, Colorado: U.S. Geol. Survey Folio of the Morrison quadrangle, Colorado, Misc. Geol. Inv. Map I-790-A.

1975, Reconnaissance geologic map of the Buena Vista quadrangle, Chaffee and Park Counties, Colorado: U.S. Geol. Survey Misc. Field Studies Map MF-657.

Scott, G. R., and Taylor, R. B., 1974, Reconnaissance geologic map of the Electric Peak quadrangle, Custer and Saguache Counties, Colorado: U.S. Geol. Survey Misc. Field Studies Map MF-628.

Scott, G. R., Taylor, R. B., Epis, R. C., and Wobus, R. A., 1976, Geologic map of the Pueblo $1^{\circ} \times 2^{\circ}$ quadrangle, south-central Colorado: U.S. Geol. Survey Misc. Field Studies Map MF-775.

Sheridan, D. M., and Marsh, S. P., 1976, Geologic map of the Squaw Pass quadrangle, Clear Creek, Jefferson, and Gilpin Counties, Colorado: U.S. Geol. Survey Geol. Quad. Map GQ-1337 (in press).

Sheridan, D. M., Maxwell, C. H., and Albee, A. L., 1967, Geology and uranium deposits of the Ralston Buttes district, Jefferson County, Colorado with sections on Paleozoic and younger sedimentary rocks by Richard Van Horn: U.S. Geol. Survey Prof. Paper $520,121 \mathrm{p}$.

Sheridan, D. M., Reed, J. C., Jr., and Bryant, Bruce, 1972, Geologic map of the Evergreen quadrangle, Jefferson County, Colorado: U.S. Geol. Survey Folio of the Evergreen quadrangle, Colorado, Misc. Geol. Inv. Map I-786-A [1973].

Silver, L. T., and Barker, Fred, 1968, Geochronology of Precambrian rocks of the Needle Mountains, southwestern Colorado-Part 1, U-Pb zircon results [abs.]: Geol. Soc. America Spec. Paper 115, p. 204-205.

Sims, P. K., 1964, Geology of the Central City quadrangle, Colorado: U.S. Geol. Survey Geol. Quad. Map GQ-267.

Sims, P. K., and Gable, D. J., 1964, Geology of Precambrian rocks, Central City district, Colorado: U.S. Geol. Survey Prof. Paper 474-C, 52 p.

Stark, J. T., and Barnes, F. F., 1932, The structure of the Sawatch Range: Am. Jour. Sci., 5 th ser., v. 24 , p. $471-480$.

1935, Geology of the Sawatch Range, Colorado: Colorado Sci. Soc. Proc., v. 13, no. 8 , p. $467-479$.

Stark, J. T., and others, 1949, Geology and origin of South Park, Colorado: Geol. Soc. America Mem. 33, 188 p.

Stern, T. W., Phair, George, and Newell, M. F., 1971, Boulder Creek batholith, Colorado, Part II-Isotopic age of emplacement and morphology of zircon: Geol. Soc. America Bull., v. 82, no. 6, p. 1615-1634.

Taylor, R. B., 1974, Reconnaissance geologic map of the Deer Peak quadrangle and southern part of the Hardscrabble Mountain quadrangle, Custer and Huerfano Counties, Colorado: U.S. Geol. Survey Misc. Geol. Inv. Map I-870 [1975].

1976, Geologic map of the Blackhawk quadrangle, Gilpin, Jefferson, and Clear Creek Counties, Colorado: U.S. Geol. Survey Geol. Quad. Map GQ-1248.

Taylor, R. B., Scott, G. R., and Wobus, R. A., 1975, Reconnaissance geologic map of the Howard quadrangle, central Colorado: U.S. Geol. Survey Misc. Geol. Inv. Map I-892. 
Taylor, R. B., Scott, G. R., Wobus, R. A., and Epis, R. C., 1975, Reconnaissance geologic map of the Cotopaxi 15-minute quadrangle, Fremont and Custer Counties, Colorado: U.S. Geol. Survey Misc. Geol. Inv. Map I-900.

Tweto, Ogden, 1974, Geologic map and sections of the Holy Cross quadrangle, Eagle, Lake, Pitkin, and Summit Counties, Colorado: U.S. Geol. Survey Misc. Geol. Inv. Map I-830 [1975].

1976, Preliminary geologic map of Colorado: U.S. Geol. Survey Misc. Field Studies Map MF-788.

Tweto, Ogden, Bryant, Bruce, and Williams, F. E., 1970, Mineral resources of the Gore Range-Eagles Nest Primitive Area and vicinity, Summit and Eagle Counties, Colorado: U.S. Geol. Survey Bull. 1319-C, 127 p.

Tweto, Ogden, and Lovering, T. S., 1977, Geology of the Minturn 15-minute quadrangle, Eagle and Summit Counties, Colorado, and general geology of the Gilman mining district: U.S. Geol. Survey Prof. Paper 956 (in press).

Tweto, Ogden, Moench, R. H., and Reed, J. C., Jr., 1976, Preliminary geologic map of the Leadville $1^{\circ} \times 2^{\circ}$ quadrangle, northwestern Colorado: U.S. Geol. Survey Misc. Field Studies Map MF-760.

Tweto, Ogden, and Pearson, R. C., 1964, St. Kevin Granite, Sawatch Range, Colorado, in Short papers in geology and hydrology: U.S. Geol. Survey Prof. Paper 475-D, p. D28-D32.

Tweto, Ogden, Steven, T. A., Hail, W. J., Jr., and Moench, R. H., 1976, Preliminary geologic map of the Montrose $1^{\circ} \times 2^{\circ}$ quadrangle, southwestern Colorado: U.S. Geol. Survey Misc. Field Studies Map MF-761.

Underhill, James, 1906, Areal geology of the lower Clear Creek [Colorado]: Colorado Sci. Soc. Proc., v. 8, p. 103-122.

Van Alstine, R. E., 1974, Geology and mineral deposits of the Poncha Springs SE quadrangle, Chaffee County, Colorado: U.S. Geol. Survey Prof. Paper 829, 19 p.

Van Horn, Richard, 1972, Surficial and bedrock geologic map of the Golden quadrangle, Jefferson County, Colorado: U.S. Geol. Survey Folio of the Golden quadrangle, Colorado, Misc. Geol. Inv. Map I-761-A.

Wahlstrom, E. E., 1940, Ore deposits at Camp Albion, Boulder County, Colorado: Econ. Geology, v. 35, no. 4, p. 477-500.

Wells, J. D., 1967, Geology of the Eldorado Springs quadrangle, Boulder and Jefferson Counties, Colorado: U.S. Geol. Survey Bull. 1221-D, 85 p.

Wells, J. D., Sheridan, D. M., and Albee, A. L., 1964, Relationship of Precambrian quartzite-schist sequence along Coal Creek to Idaho Springs Formation, Front Range, Colorado: U.S. Geol. Survey Prof. Paper 454-O, 25 p.

Wetherill, G. W., and Bickford, M. E., 1965, Primary and metamorphic Rb-Sr chronology in central Colorado: Jour. Geophys. Research, v. 70, no. 18, p. 4669-4686.

Wrucke, C. T., and Wilson, R. F., 1967, Geologic map of the Boulder quadrangle, Boulder County, Colorado: U.S. Geol. Survey Open-file rept. 



